\title{
Charcot-Marie-Tooth Disease Type 2A1
}

National Cancer Institute

\section{Source}

National Cancer Institute. Charcot-Marie-Tooth Disease Type 2A1. NCI Thesaurus. Code C150609.

An autosomal dominant sub-type of Charcot-Marie-T ooth disease caused by mutation(s) in the KIF1B gene, encoding kinesin-like protein KIF1B. 